(c) American Dairy Science Association, 2002.

\title{
Markers of Oxidative Status in Plasma and Erythrocytes of Transition Dairy Cows During Hot Season ${ }^{1}$
}

\author{
U. Bernabucci, B. Ronchi, N. Lacetera, and A. Nardone \\ Department of Animal Production, \\ University of Tuscia, \\ via C. De Lellis, 01100 Viterbo, Italy
}

\section{ABSTRACT}

The study was carried out to assess whether hot seasons affect the oxidative status of transition dairy cows. Twenty Holstein cows were utilized. Eleven of those cows gave birth in spring; the remaining nine cows gave birth in summer. Oxidative status was evaluated from $21 \mathrm{~d}$ before to $35 \mathrm{~d}$ after calving, determining oxidative markers in plasma [glutathione peroxidase activity, thiol groups, reactive oxygen metabolites, and thiobarbituric acid reactive substances (TBARS)] and in erythrocytes [glutathione peroxidase activity (GSH-Px-E), intracellular thiols ( $\mathrm{SH})$, superoxide dismutase activity (SOD) and TBARS]. The season did not modify plasma oxidative markers. In contrast, cows exposed to moderate heat stress $\left(39.5 \pm 0.2^{\circ} \mathrm{C}\right.$ rectal temperatures $)$ due to summer temperature-humidity index (73.2 \pm 2.5 mean daily THI), showed higher erythrocyte SOD, GSH-Px$\mathrm{E}, \mathrm{SH}$, and TBARS compared with spring cows, indicating a condition of oxidative stress in summer transition dairy cows. Some changes (the increase of SOD, for example), represent compensatory changes the cow is undergoing in response to increased oxidative stress. Under the conditions compared, the effect of heat stress on oxidative status in transition dairy cows by use of plasma markers does not give enough information to reach definitive conclusions. Erythrocytes are an appropriate and sensitive model to study the oxidative status of transition dairy cows exposed to hot environments. (Key words: oxidative status marker, hot environment, transition dairy cow)

\footnotetext{
Abbreviation key: GSH-Px-E = erythrocyte glutathione peroxidase, GSH-Px-P = plasma glutathione peroxidase, $\mathbf{M D A}=$ malondialdehyde, $\mathbf{P C V}=$ packed cells volume, $\mathbf{R O M}=$ reactive oxygen metabolites, $\mathbf{R R}=$ respiration rates, $\mathbf{R T}=$ rectal temperatures, $\mathbf{S H}=$ intracellular thiols, $\mathbf{S H p}=$ plasma thiols, $\mathbf{S O D}=$ superoxide

Received December 21, 2001.

Accepted April 8, 2002.

Corresponding author: U. Bernabucci; e-mail: bernab@unitus.it.

${ }^{1}$ Research was financially supported by M.U.R.S.T.-Cofinanziamento 1999.
}

dismutase, $\mathbf{S P}=$ spring, $\mathbf{S U}=$ summer, $\mathbf{T B A R S}=$ thiobarbituric acid reactive substances, THI $=$ temperature-humidity index.

\section{INTRODUCTION}

Oxidative stress resulting from increased production of free radicals and reactive oxygen species, and/or a decrease in antioxidant defense, leads to damage of biological macromolecules and disruption of normal metabolism and physiology (Trevisan et al., 2001). When reactive forms of oxygen are produced faster than they can be safely neutralized by antioxidant mechanisms, oxidative stress results (Sies, 1991). These conditions can contribute and/or lead to the onset of health disorders in cattle (Miller et al., 1993).

The transition period is critical for the health of dairy cattle (Drackley, 1999). It has been observed that during the transition period cows can experience oxidative stress (Miller and Madsen, 1994; Formigoni et al., 1997; Ronchi et al., 2000), which may contribute to periparturient disorders (Miller et al., 1993; Brezezinska-Slebodzinska et al., 1994), and may be associated with metabolic diseases (Ronchi et al., 2000).

Studies on the effects of heat stress on oxidative status in cattle are lacking, and only preliminary reports are available. Harmon et al. (1997) reported a reduction of antioxidant activity of plasma in midlactating heatstressed Holstein cows. Trout et al. (1998) reported no effects of heat stress on plasma concentration of vitamin $\mathrm{E}$ and $\beta$-carotene or on muscle content of thiobarbituric acid reactive substances. Calamari et al. (1999) observed weak negative effects of heat stress on some plasma markers of oxidative status in midlactating cows.

To our knowledge, studies on the effects of exposure to hot environments on the oxidative status of transition dairy cows are not available. We assumed that the oxidative status of transition dairy cows might be impaired by heat stress. Oxidative stress can be monitored with several biomarkers (antioxidants and pro-oxidants) which can be assessed in plasma and/or erythrocytes (Passi et al., 2001). To verify our hypothesis, we ana- 
Table 1. Ingredients and nutrients compositions of diets fed during spring and summer experimental periods (DM basis).

\begin{tabular}{|c|c|c|c|}
\hline & $\begin{array}{l}\text { Far-off } \\
\text { dry cows }\end{array}$ & $\begin{array}{l}\text { Close-up } \\
\text { dry cows }\end{array}$ & $\begin{array}{l}\text { Lactation } \\
\text { cows }\end{array}$ \\
\hline \multicolumn{4}{|l|}{ Ingredients } \\
\hline Corn silage, $\%$ & 14.4 & 20.0 & 28.0 \\
\hline Triticale-grass silage, $\%$ & 2.9 & 4.0 & 5.6 \\
\hline Alfalfa hay, \% & 5.2 & 7.3 & 10.2 \\
\hline Rye-grass hay, \% & 51.8 & 33.0 & 6.1 \\
\hline Corn ground, \% & 6.2 & 8.6 & 12.2 \\
\hline Oat ground, \% & 7.2 & 10.0 & 14.1 \\
\hline Soybean meal, \% & 5.5 & 7.5 & 10.7 \\
\hline Cotton seed, \% & 3.4 & 4.8 & 6.5 \\
\hline Dry beet pulp, \% & 2.6 & 3.6 & 5.1 \\
\hline Buffer $^{1}, \%$ & 0.5 & 0.7 & 0.9 \\
\hline Vitamin-mineral premix ${ }^{2}, \%$ & 0.3 & 0.5 & 0.6 \\
\hline \multicolumn{4}{|l|}{ Nutrient composition } \\
\hline $\mathrm{NE}_{\mathrm{L}}, \mathrm{Mcal} / \mathrm{kg}$ & 1.29 & 1.41 & 1.62 \\
\hline Crude proteins, $\%$ & 12.70 & 13.70 & 15.60 \\
\hline NDF, $\%$ & 43.10 & 40.00 & 36.40 \\
\hline
\end{tabular}

${ }^{1} \mathrm{~A}$ mixture of $33.3 \% \mathrm{CaCO}_{3}, 31.7 \mathrm{Ca}_{3}\left(\mathrm{PO}_{4}\right)_{2}, 16.7 \% \mathrm{MgO}, 16.6 \% \mathrm{NaHCO}_{3}$, and $1.7 \% \mathrm{ZnSO}_{4}$.

${ }^{2}$ Contained: $6,000,000 \mathrm{IU}$ of vitamin A, 600,000 IU of vitamin $\mathrm{D}_{3}, 7,000 \mathrm{mg}$ of vitamin $\mathrm{E}, 5,000 \mathrm{mg}$ of vitamin $\mathrm{PP}, 300 \mathrm{mg}$ of vitamin $\mathrm{B}_{1}, 100 \mathrm{mg}$ of vitamin $\mathrm{B}_{2}, 10,000 \mathrm{mg}$ of choline chloride, $2 \mathrm{mg}$ of vitamin $\mathrm{B}_{12}, 10,000 \mathrm{mg}$ of $\mathrm{Fe}, 2,500 \mathrm{mg}$ of $\mathrm{Cu}, 20,000 \mathrm{mg}$ of $\mathrm{Mn}, 100 \mathrm{mg}$ of Mo, $100 \mathrm{mg}$ of Co, $800 \mathrm{mg}$ of I, 50,000 $\mathrm{mg}$ of $\mathrm{Zn}$, and $100 \mathrm{mg}$ of Se per kilogram.

lyzed changes in several markers of oxidative status in plasma and in the erythrocytes of transition Holstein dairy cows reared during the hot season (summer), and during a season characterized by thermoneutral conditions (spring).

\section{MATERIALS AND METHODS}

\section{Experimental Design, Animals, and Feeding}

The experiment was carried out from April until the end of August in a commercial dairy herd located in central Italy, approximately $50 \mathrm{~km}$ south of Rome $\left(13^{\circ} 00^{\prime}\right.$ North, $42^{\circ} 72^{\prime}$ East). Twenty Holstein cows were utilized. Eleven cows gave birth during spring (SP cows), in a period from April 13 to May 12. The remaining 9 cows gave birth during summer (SU cows), in a period between June 27 and August 26. Spring cows and SU cows were similar for parity $(2.6 \pm 2.1$ and $2.8 \pm 2.2$ for SP and SU cows, respectively). During both SP and SU, diets for dry cows and lactating cows consisted of a base-ration fed as a TMR given daily at 0930, and offered ad libitum to achieve 5 to $10 \%$ refusals. The close-up diet was offered during the last $10 \mathrm{~d}$ before the expected calving. All diets were kept constant for the entire experimental period (Table 1).

\section{Measurements and Samplings}

Temperature and relative humidity of the air were measured and recorded at 1-h intervals using electronic recorder stations (Data-Hog recorders, Skye Instru- ments Ltd., Llandrindod Wells, UK). Temperature-humidity index (THI) was calculated according to the formula reported by Ingraham et al. (1979). The animals were monitored during the last $3 \mathrm{wk}$ of pregnancy and the first $35 \mathrm{~d}$ of lactation. Rectal temperatures (RT) and respiration rates $(\mathbf{R R})$ were registered at $-21,-3$, $+1,+15$, and $+35 \mathrm{~d}$ from calving at $1500 \mathrm{~h}$. On the same days, blood samples were taken from the jugular vein using Vacutainer tubes containing lithium heparin as an anticlotting agent and put in ice.

\section{Laboratory Analyses}

Within $2 \mathrm{~h}$ of the bleedings, packed cell volume (PCV) was determined by microhemocytometer, and blood samples were centrifuged at $3500 \mathrm{rpm}$ for $10 \mathrm{~min}$ at $4^{\circ} \mathrm{C}$ and plasma was thus separated. Erythrocytes were obtained by centrifuging $0.5 \mathrm{ml}$ of blood at $3500 \mathrm{rpm}$ for $10 \mathrm{~min}$. Erythrocytes were then washed four times with $3 \mathrm{ml}$ of $0.9 \% \mathrm{NaCl}$ solution, by centrifuging for 10 $\mathrm{min}$ at $2200 \times \mathrm{g}$. After the final wash, the red blood cells were lysed by hypotonic shock using $2.0 \mathrm{ml}$ of cold redistilled water. The hemolysate was mixed and left at $4^{\circ} \mathrm{C}$ for $15 \mathrm{~min}$. The plasma and the lysate of erythrocytes were then analyzed.

Plasma reactive oxygen metabolites (ROM) were measured by the analytical method patented by Diacron (Cesarone et al., 1999). The results of the analyses were expressed in arbitrary units (a.u.). The value of 1 a.u. corresponds to a concentration of $0.08 \mathrm{mg} / \mathrm{dl}$ of hydrogen peroxide. 
Erythrocyte glutathione peroxidase (GSH-Px-E) and plasma glutathione peroxidase (GSH-Px-P) activities were determined by a kinetic method with a commercial kit (RANSEL by Randox Laboratories, UK), and were expressed in international units per milliliter of PCV and international units per milliliter, respectively.

To determine superoxide dismutase activity in erythrocytes (SOD), the lysate was diluted 50-fold with 0.01 $\mathrm{mmol} / \mathrm{L}$ phosphate buffer, $\mathrm{pH}$ 7.0, and then SOD was measured by a kinetic method using a commercial kit (RANSOD, by Randox Laboratories), and results were expressed in international units per milliliter.

Intracellular thiol contents of lysates of erythrocytes (SH) (Kusmic et al., 2000) and plasma thiol groups (SHp) were determined by titration with 5,5-dithiobis2-nitrobenzoic acid by use of commercial kit (Diacron, Italy), and were expressed in micromoles per milliliter of PCV and in micromoles per liter, respectively.

Thiobarbituric acid reactive substances (TBARS) in erythrocyte lysates and plasma were measured by the fluorimetric method of Maseki et al. (1981) and were expressed in nanomoles malondialdehyde (MDA) equivalents per milliliter of lysate.

\section{Statistical Analysis}

Data were analyzed as repeated measures using the GLM procedure of SAS (SAS, 1996) by multifactorial models with interactions including season, cows within season, days from calving, and the physiological phase (pregnancy or lactation) as main effects, and an error term. To isolate the variation due to cow from variation due to season, the error term used to test for a season effect was cow within season. Least squares means were separated with the PDIFF procedure of SAS (SAS, 1996). Significance was declared at $P<0.05$.

\section{RESULTS}

\section{Climatic Conditions and Clinical Parameters}

During spring, mean daily values of THI were 58.5 \pm 3.7 during the daytime (from 0900 to $2000 \mathrm{~h}$ ), and $53.3 \pm 4.0$ during the nighttime (from 2100 to $0800 \mathrm{~h}$ ). In summer, mean daily values of THI were equal to $75.2 \pm 2.6$ during the daytime, and to $71.2 \pm 2.5$ during the nighttime (Figure 1).

Values of RT differed significantly between SU and SP cows (39.5 vs. $39.1^{\circ} \mathrm{C}, P<0.01$, in SU and SP cows, respectively). Analogously, values of $R R$ were higher $(P<0.001)$ in SU cows when compared with their SP counterparts ( 60.3 vs. 35.8 breaths/min, respectively).
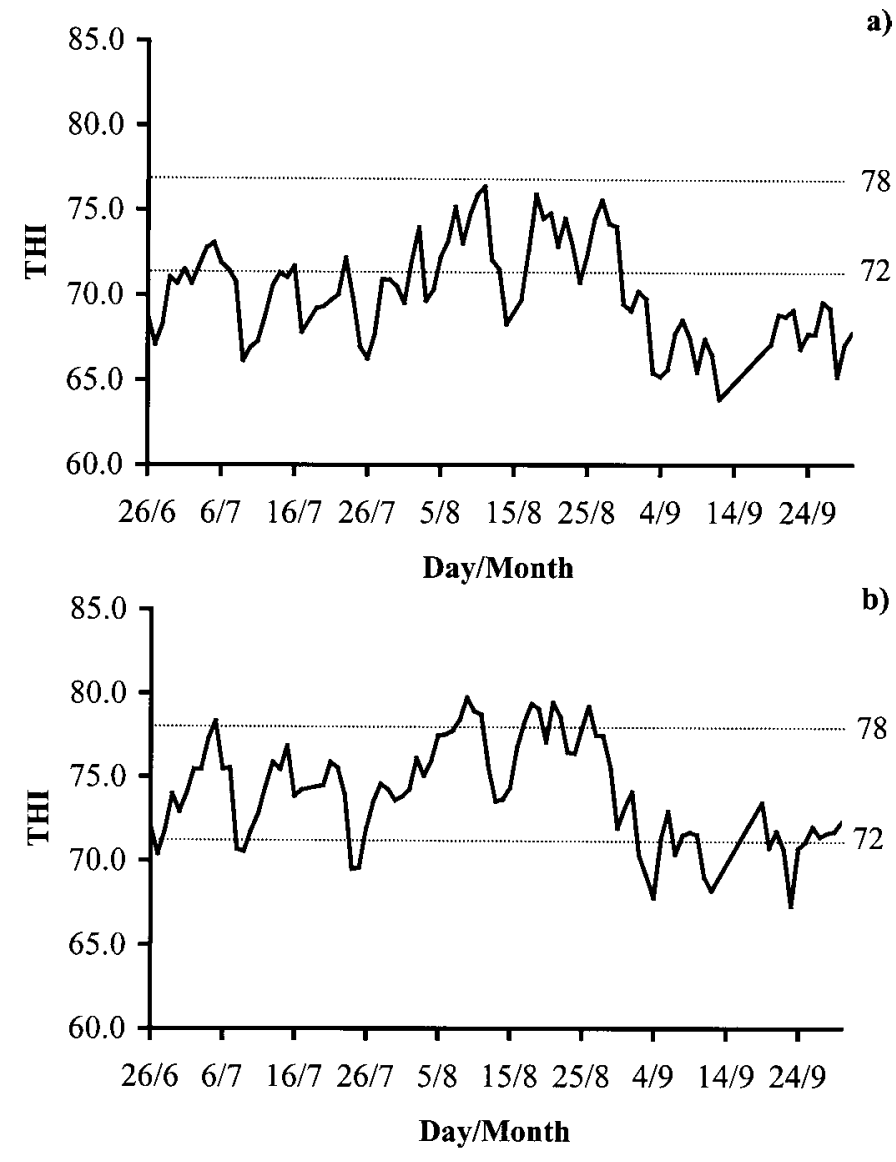

Figure 1. Mean daily values of temperature-humidity index (THI) during the night-time (a: from 2100 to $0800 \mathrm{~h}$ ) and during the daytime (b: from 0900 to $2000 \mathrm{~h}$ ), in summer seasons. The range between 72 and 78 THI values indicates a moderate heat stress condition (Armstrong, 1994).

\section{Oxidative Status}

Plasma concentration of TBARS (Table 2) and concentration of SHp and activity of GSH-Px-P did not significantly differ between SU and SP cows (Figure $2)$. Lower $(P<0.05)$ plasma ROM concentration were observed in $\mathrm{SU}$ cows at $+35 \mathrm{~d}$ from calving, compared with their SP counterparts (Table 2).

Erythrocyte TBARS, SOD, and SH were higher $(P$ ranging from $<0.05$ to $<0.01)$ in SU cows than in their SP counterparts (Table 3). Summer cows also showed higher $(P<0.05)$ GSH-Px-E activity at $-21 \mathrm{~d}$ from calving, and higher $(P<0.01)$ GSH-Px-E activity between the average values of the transition period compared with their counterparts (54.6 vs. $62.8 \mathrm{U} / \mathrm{ml} \mathrm{PCV}$ in SP and SU cows, respectively).

Evolution of plasma and erythrocyte markers of the oxidative status during the transition period were similar between the two groups of cows (Tables 2 and 3, Figure 2): activity of SOD, GSH-Px-P, and GSH-Px- 
Table 2. Least square means $\pm \mathrm{SE}$ of plasma reactive oxygen metabolites (ROM) and plasma lipid peroxidation-end products (TBARS) in summer (SU) and spring (SP) cows during the transition period.

\begin{tabular}{llrrrrr}
\hline & \multicolumn{7}{c}{ Days from calving } \\
\cline { 2 - 7 } & & \multicolumn{1}{c}{-21} & \multicolumn{1}{c}{-3} & \multicolumn{1}{c}{1} & \multicolumn{1}{c}{15} & \multicolumn{1}{c}{35} \\
\hline $\mathrm{ROM}, \mathrm{mg} \mathrm{H} \mathrm{O}_{2} / \mathrm{dl}$ & $\mathrm{SU}$ & $10.3 \pm 1.1$ & $10.2 \pm 1.2$ & $10.5 \pm 1.2$ & $11.7 \pm 1.2$ & $11.5 \pm 1.1^{\mathrm{a}}$ \\
& $\mathrm{SP}$ & $9.4 \pm 0.9$ & $9.1 \pm 1.0$ & $9.8 \pm 0.9$ & $11.7 \pm 0.9$ & $15.7 \pm 1.0^{\mathrm{b}}$ \\
$\mathrm{TBARS}, \mathrm{nmol} / \mathrm{ml}$ & $\mathrm{SU}$ & $1.5 \pm 0.14$ & $1.5 \pm 0.14$ & $1.7 \pm 0.14$ & $2.0 \pm 0.14$ & $1.9 \pm 0.15$ \\
& $\mathrm{SP}$ & $1.9 \pm 0.15$ & $1.6 \pm 0.14$ & $1.8 \pm 0.14$ & $1.9 \pm 0.15$ & $2.0 \pm 0.15$ \\
\hline
\end{tabular}

${ }^{\mathrm{a}, \mathrm{b}}$ Mean within column with different superscript within parameter $\operatorname{differ}(P<0.05)$.

$\mathrm{E}$ and concentrations of SHp and $\mathrm{SH}$ peaked around calving (between -3 and $+1 \mathrm{~d}$ from calving). Mean values after calving did not differ from those registered before calving, however. Plasma concentrations of ROM and TBARS tended to increase postpartum, showing higher values $(P<0.05)$ after calving.

\section{DISCUSSION}

Values of the daytime THI recorded during SU indicated conditions capable of inducing a moderate heat
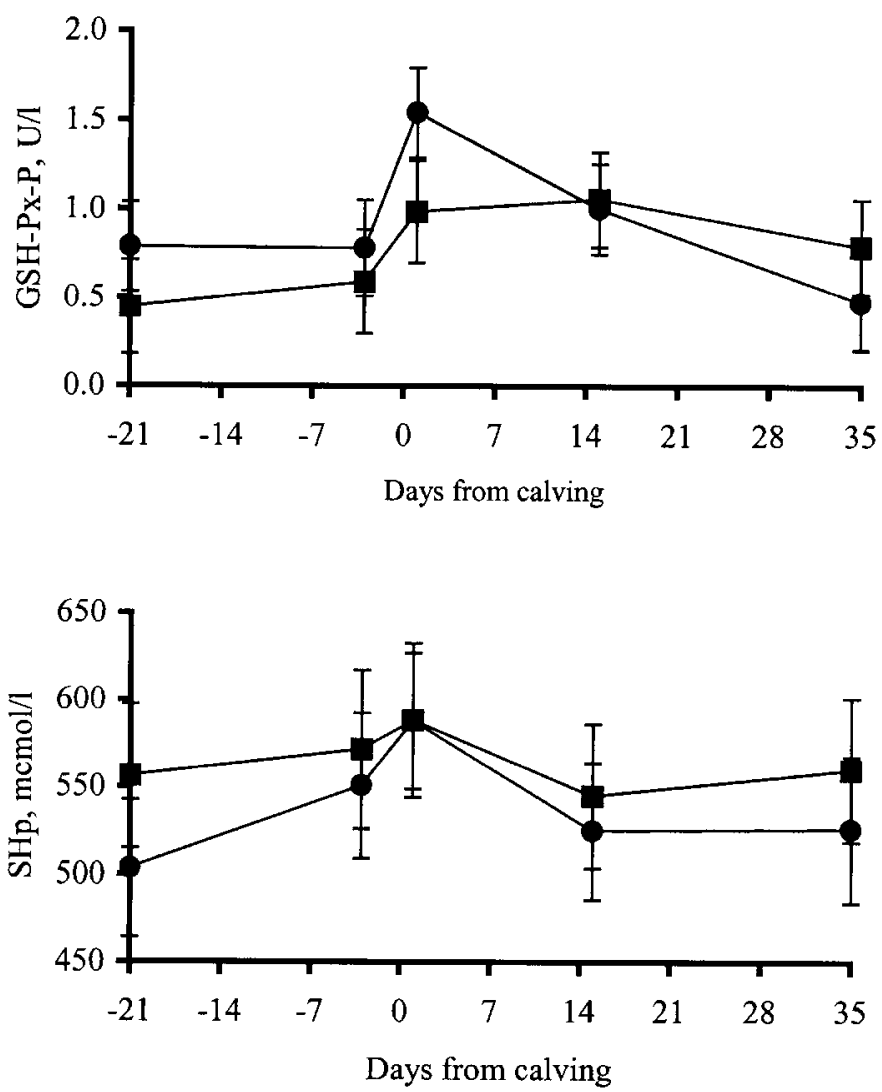

Figure 2. Changes of plasma glutathione peroxidase activity (GSH-Px-P) and thiol groups concentration (SHp) of transition dairy cows during summer (ם) or spring (@) periods. stress (Armstrong, 1994). Values of RT and RR of SU cows confirmed conditions of moderate stress (Johnson, 1987).

Even if the possibility that the differences found in the oxidative status of spring and summer cows were also partially dependent on other seasonal factors cannot be excluded, previous studies that referred to other species (Bellò-Klein et al., 2000) indicated that seasonal alterations of the oxidative status depend more on weather conditions such as temperature and humidity. For this reason, and for lack of information on the effects of other seasonal factors on the oxidative status of dairy cows, this discussion will provide a possible interpretation of our results in light of literature on the effects of heat stress on oxidative status.

In the present study, we found that plasma markers of the oxidative status in moderately heat-stressed cows did not differ from those observed in SP cows. Unfortunately, previous studies on heat stress and oxidative status of dairy cows were carried out only in midlactating animals (Harmon et al., 1997; Trout et al., 1998; Calamari et al., 1999). Harmon et al. (1997) reported the reduction of antioxidant activity of plasma in midlactating cows exposed to a chamber temperature of $29.5^{\circ} \mathrm{C}$, and when THI reached danger level for livestock during summer. Calamari et al. (1999) found a reduction of plasma lipid soluble antioxidants (vitamin $\mathrm{E}$ and $\beta$-carotene), and an increase of plasma TBARS in moderately heat-stressed, midlactation cows during summer. Trout et al. (1998) reported no effects of short exposure to a hot environment on the concentration of lipid soluble antioxidants ( $\alpha$-tocopherol, $\beta$-carotene, retinol, and retinyl palmitate) or on the concentration of MDA in muscle. The different physiological status of cows between previous studies and our own might be responsible for the discrepancy between our results and those of said previous studies.

In contrast, we found significant differences in the oxidative status of SU and SP cows by observing erythrocyte markers. In particular, SU cows showed higher erythrocyte SOD, GSH-Px-E, SH, and TBARS, which would indicate some effects of moderate hot summer weather on the oxidative status of transition dairy cows. 
Table 3. Least square means \pm SE of erythrocyte lipid peroxidation-end products (TBARS) concentration, superoxide dismutase activity (SOD), glutathione peroxidase (GSH-Px-E) activity, and intracellular thiols (SH) concentration of summer (SU) and spring (SP) cows during the transition period.

\begin{tabular}{|c|c|c|c|c|c|c|}
\hline & & \multicolumn{5}{|c|}{ Days from calving } \\
\hline TBARS, nmol/ml & $\begin{array}{l}\text { SU } \\
\text { SP }\end{array}$ & $\begin{array}{l}8.3 \pm 0.4^{\mathrm{B}} \\
7.5 \pm 0.4^{\mathrm{A}}\end{array}$ & $\begin{array}{l}9.1 \pm 0.4^{\mathrm{b}} \\
7.5 \pm 0.4^{\mathrm{a}}\end{array}$ & $\begin{array}{r}10.2 \pm 0.4^{\mathrm{B}} \\
7.0 \pm 0.4^{\mathrm{A}}\end{array}$ & $\begin{array}{l}8.6 \pm 0.4 \\
8.1 \pm 0.4\end{array}$ & $\begin{array}{l}8.8 \pm 0.4^{\mathrm{b}} \\
7.6 \pm 0.4^{\mathrm{a}}\end{array}$ \\
\hline $\mathrm{SOD}, \mathrm{U} / \mathrm{ml}$ & $\begin{array}{l}\text { SU } \\
\text { SP }\end{array}$ & $\begin{array}{l}176.4 \pm 19.8 \\
141.4 \pm 18.8\end{array}$ & $\begin{array}{l}194.3 \pm 20.3^{\mathrm{b}} \\
140.5 \pm 20.0^{\mathrm{a}}\end{array}$ & $\begin{array}{l}215.3 \pm 21.3^{\mathrm{b}} \\
179.0 \pm 18.8^{\mathrm{a}}\end{array}$ & $\begin{array}{l}192.8 \pm 21.3^{\mathrm{b}} \\
143.0 \pm 18.8^{\mathrm{a}}\end{array}$ & $\begin{array}{l}153.0 \pm 19.8^{\mathrm{b}} \\
172.8 \pm 20.0^{\mathrm{a}}\end{array}$ \\
\hline GSH-Px-E, U/ml PCV ${ }^{1}$ & $\begin{array}{l}\text { SU } \\
\text { SP }\end{array}$ & $\begin{array}{l}65.7 \pm 3.9^{\mathrm{b}} \\
46.4 \pm 3.7^{\mathrm{a}}\end{array}$ & $\begin{array}{l}69.6 \pm 4.0 \\
62.3 \pm 4.0\end{array}$ & $\begin{array}{l}59.4 \pm 4.2 \\
56.0 \pm 3.7\end{array}$ & $\begin{array}{l}62.9 \pm 3.9 \\
56.9 \pm 3.7\end{array}$ & $\begin{array}{l}56.6 \pm 3.9 \\
52.2 \pm 4.0\end{array}$ \\
\hline
\end{tabular}

${ }^{1} \mathrm{PCV}=$ Packed cells volume.

${ }^{\mathrm{a}, \mathrm{b}}$ Mean within column with different superscript within parameter $\operatorname{differ}(P<0.05)$.

${ }^{\mathrm{A}, \mathrm{B}}$ Mean within column with different superscript within parameter differ $(P<0.01)$.

The role of intracellular SOD is to scavenge the superoxide $\left(\bullet \mathrm{O}_{2}^{-}\right)$that is produced by a number of reaction mechanisms, including several enzyme systems, as a part of normal cellular functions (Fee et al., 1975). In particular, the oxidation or autooxidation of hemoglobin $\left(\mathrm{Hb}-\mathrm{Fe}^{2+}\right.$ into $\left.\mathrm{Hb}-\mathrm{Fe}^{3+}\right)$ into the erythrocytes results in the continuous formation of $\bullet \mathrm{O}_{2}^{-}$(Hebbel and Easton, 1989). In this study, the higher erythrocyte SOD activity found in SU cows was probably a response to the higher $\bullet \mathrm{O}_{2}{ }^{-}$generation. SOD catalyzes the dismutation of $\bullet \mathrm{O}_{2}{ }^{-}$into oxygen and hydrogen peroxide $\left(\mathrm{H}_{2} \mathrm{O}_{2}\right)$, and it is an important antioxidant defense mechanism in aerobic organisms, although too much SOD may sometimes be deleterious (Halliwell and Chirico, 1993). In fact, the dismutation of $\bullet \mathrm{O}_{2}^{-}$results in a rise in $\mathrm{H}_{2} \mathrm{O}_{2}$. Since SOD activity increases $\mathrm{H}_{2} \mathrm{O}_{2}$ production, protection from reactive oxygen would only be conferred by a coordinate increase of catalase and GSH-Px-E activities (Clemens and Waller, 1987; Frei, 1994; Kehrer and Smith, 1994). In support of this conjecture, GSH-Px-E was found to be increased in SU cows. The decomposition of $\mathrm{H}_{2} \mathrm{O}_{2}$ or its interaction with $\bullet \mathrm{O}_{2}{ }^{-}$would generate hydroxyl radicals $(\mathrm{OH} \bullet)$ (Hochstein and Jain, 1981). Hydroxyl radicals can attack all biological molecules, including membrane lipids, and can result in initiation of lipid peroxidation (Halliwell and Chirico, 1993).

The resulting lipid-centered free radicals rearrange and react with molecular oxygen to form lipid hydroperoxides (Trevisan et al., 2001). Hydrolysis of lipid hydroperoxide leads to a complex mixture of small acyl compounds aldehydes, alcohols, and hydrocarbons (Armstrong and Browne, 1994). One of the commonly applied assays to estimate lipid peroxidation is the thiobarbituric acid test. Thiobarbituric acid reacts with MDA to form a fluorescent adduct. However, thiobarbituric acid is not specific for MDA, and the test is considered to be a good general indicator of oxidative stress rather than a marker of lipid peroxidation (Armstrong and Browne, 1994). The increment in erythrocyte TBARS indicates that the balance between the oxidants and the antioxidants favors the former.

The method we used to assess thiol content is unable to distinguish the GSH from the other free thiols. However, it represents a fast and easy tool to observe the response at cytosolic level (Kusmic et al., 2000) and provides a good estimation of total intracellular GSH content, since GSH represents about 95\% of the intracellular thiols (van den Berg et al., 1992). Glutathione plays an important role in protecting cells against oxidative stress and toxic agents (Zollner et al., 1991; Cnubben et al., 2001), and it is a substrate for GSHPx-E (Sies, 1991). The increase of cellular GSH and total intracellular - $\mathrm{SH}$ groups would indicate a higher exposure of the erythrocytes to the risk of oxidative stress (Yu, 1994; Ohtsuka et al., 1997; John et al., 2001). John et al. (2001) reported that the increase of -SH groups in oxidative-stressed erythrocytes could be due to the decrease of glutathione-S-transferase activity of erythrocytes. The same authors suggested that the lower conjugation of - $\mathrm{SH}$ groups due to the decrease of glutathione-S-transferase activity may cause toxic conditions in the erythrocytes.

We speculate that the coordinate increase of erythrocyte SOD, GSH-Px-E, and SH is an indirect compensatory response of cells to increased oxidant challenge during heat stress. In the present study, the concentrations of TBARS were significantly higher in erythrocytes of heat-stressed cows which, in parallel with increased erythrocyte enzymes activity and SH concentration, supported the hypothesis that heat stress represents an oxidative challenge for erythrocytes and causes alterations in the antioxidant status of these cells. 
The combination of moderate heat stress conditions and the elevated antioxidant capacity of plasma (Frei et al., 1998) might be the reason for the absence of differences between seasons in plasma oxidative markers found in our study. In contrast, the high polyunsaturated fatty acid content of erythrocyte membrane, and the continuous exposure to high concentration of oxygen and iron in hemoglobin are the factors that make erythrocytes very sensitive to the oxidative injury (Clemens and Waller, 1987) and make erythrocytes an appropriate model to study oxidative stress (Kusmic et al., 2000; Alicigüzel et al., 2001).

In a recent study on hyperthyroid patients, Alicigüzel et al. (2001) hypothesized the hypermetabolic effects of thyroid hormones as the cause of erythrocyte oxidative stress. In our instance we can exclude the hyperthyroidism and the hypermetabolism as the causes, since it is well known that thyroid hormones and metabolism are decreased when dairy cows are heat-stressed (Webster, 1991; Nardone et al., 1997). Under heat stress, the increase of oxygen pressure of blood due to the increased RR (unpublished data) might be the cause of alteration of oxidative status. As reported before, the high polyunsaturated fatty acid content of erythrocyte membrane and the presence of high concentration of iron in hemoglobin may result in oxygen toxicity via generation of free radicals (DiGiuseppi et al., 1984) that could in turn cause alteration in erythrocyte antioxidant defense systems.

Noble et al. (1976) observed a reduction of the proportion of linoleic acid $\left(\mathrm{C}_{18: 2}\right)$ in the cholesteryl ester fraction from cattle exposed to hot environments. Kuiper et al. (1971) cited by Noble et al. (1976), found a reduction of $\mathrm{C}_{18: 2}$ concentration in the erythrocyte membrane from heat-stressed hamsters. Linoleic acid is one of the principal polyunsaturated fatty acids of cell membranes, which is sensitive to lipid peroxidation process (Zollner et al., 1991). Utoh and Harasaki (1992) reported an increase of membrane fragility in erythrocytes exposed to high in vitro temperatures. Oxidative stress can lead to increase in TBARS (Halliwell and Chirico, 1993), and the cytotoxic effects of TBARS are well known (Zollner et al., 1991). In particular, TBARS can induce a reduction of membrane fluidity (Chen and $\mathrm{Yu}, 1994)$, and increase erythrocyte membrane fragility (Spicket et al., 1998).

Data from our study that show an alteration of erythrocyte oxidative status with the increase of TBARS in heat-stressed cows might explain the reduction of $\mathrm{C}_{18: 2}$ and the increase of erythrocyte membrane fragility as a consequence of exposure to hot condition.

Variation of plasma and erythrocyte oxidants and antioxidants during the transition period observed in the present study revealed an alteration of the oxidative status after calving. These results confirm our previous (Ronchi et al., 2000) and others' (Miller et al., 1993; Formigoni et al., 1997) findings that clearly indicated an imbalance of the oxidative status during the early lactation phase in Holstein cows. It can be concluded that a hot environment is responsible for oxidative stress, which worsens the alteration of oxidative status commonly observed in transition dairy cows.

\section{CONCLUSIONS}

Summer conditions capable of producing moderate heat stress cause oxidative stress in transition dairy cows.

Erythrocytes are an appropriate and sensitive model for studing the oxidative status of moderately heatstressed transition dairy cows. In contrast, the evaluation of the effect of moderate heat stress on oxidative status in transition dairy cows by use of plasma markers does not give enough information to reach definitive conclusions.

Finally, an increase of SOD and a concentration of $\mathrm{SH}$ in erythrocytes are likely to represent adaptive changes of cows in response to heat stress.

\section{ACKNOWLEDGMENTS}

The authors acknowledge the able technical help provided by C. Bruti, R. Signorelli, and A. Colagiacomo.

\section{REFERENCES}

Alicigüzel, Y., S. N. Özdem, S. S. Özdem, Ü. Karayalçin, S. L. Siedlak, G. Perry, and M. A. Shith. 2001. Erythrocyte, plasma, and serum antioxidant activities in untreated toxic multinodular goiter patients. Free Radic. Biol. Med. 30:665-670.

Armstrong, D. V. 1994. Heat stress interaction with shade and cooling. J. Dairy Sci. 77:2044-2050

Armstrong, D., and R. Browne. 1994. The analysis of free radicals, lipid peroxides, antioxidant enzymes and compounds related to oxidative stress as applied to the clinical chemistry laboratory. Adv. Exp. Med. Biol. 366:43-58.

Belló-Klein, A., M. I. Morgan-Martins, J. Barp, S. Llesuy, A. A. Belló, and P. K. Singal. 2000. Circaannual changes in antioxidants and oxidative stress in the heart and liver in rats. Comp. Biochem. Physiol. C 126:203-208.

Brezezinska-Slebodzinska, E., J. K. Miller, J. D. Quigley, and J. R. Moore. 1994. Antioxidant status of dairy cows supplemented prepartum with vitamin E and selenium. J. Dairy Sci. 77:3087-3095.

Calamari, L., M. G. Maianti, F. Amendola, and G. Lombardi. 1999. On some aspects of the oxidative status and on antioxidants in blood of dairy cows during summer. Pages 449-451 in Proc. 13th Associazione Scientifica Produzioni Animali Congress, Piacenza, Italy.

Cesarone, M. R., G. Belcaro, and M. Caratelli. 1999. A simple test to monitor oxidative stress. Int. Angiol. 18:127-130.

Chen, J. J., and B. P. Yu. 1994. Alteration in mitocondrial membrane fluidity by lipid peroxidation products. Free Radic. Biol. Med. 17:411-418.

Clemens, M. C., and H. D. Waller. 1987. Lipid peroxidation in erythrocytes. Chem. Phys. Lipids. 45:251-268. 
Cnubben, N. H. P., I. M. C. M. Rietjens, H. Wortelboer, J. van Zanden, and P. J. van Bladeren. 2001. The interplay of glutathione-related processes in antioxidant defense. Environ. Toxicol. Pharmacol. 10:141-152.

DiGiuseppi, J., and I. Fridovich. 1984. The toxicity of molecular oxygen. Crit. Rev. Toxicol. 12:315-342.

Drackley, J. K. 1999. Biology of dairy cows during the transition period: the final frontier? J. Dairy Sci. 82:2259-2273.

Fee, J., R. Bergamini, and R. Briggs. 1975. Observation on the mechanism of the oxygen dialuric acid induced hemolysis of vitamin Edeficient rat blood cells and the protective roles of catalase and superoxide dismutase. Arch. Biochem. Biophys. 169:160-167.

Formigoni, A., D. Calderone, P. Pezzi, and A. Panciroli. 1997. Evolution of oxidative status in dairy cows: preliminary observations. Pages 203-204 in Proc. 12th Associazione Scientifica Produzioni Animali Congress, Pisa.

Frei, B. 1994. Natural Antioxidants in Human Health and Disease. Academic Press, San Diego, CA.

Frei, B., R. Stocker, and B. N. Ames. 1998. Antioxidant defenses and lipid peroxidation in human blood plasma. Proc. Natl. Acad. Sci. USA 85:9748-9752.

Halliwell, B., and S. Chirico. 1993. Lipid peroxidation: its mechanism, measurement, and significance. Am. J. Clin. Nutr. 57:715S-725S.

Harmon, R. J., M. Lu, D. S. Trammel, and B. A. Smith. 1997. Influence of heat stress and calving on antioxidant activity in bovine blood. J. Dairy Sci. 80(Suppl. 1):264. (Abstr.)

Hebbel, R. P., and J. W. Easton. 1989. Pathobiology of heme interaction with erythrocyte membrane. Semin. Hematol. 26:136-149.

Hochstein, P., and S. K. Jain. 1981. Association of lipid peroxidation and polymerization of membrane proteins with erythrocytes aging. FASEB Proc. 40:183-188.

Ingraham, R. H., R. W. Stanley, and W. C. Wagner. 1979. Seasonal effects of tropical climate on shaded and nonshaded cows as measured by rectal temperature, adrenal cortex hormones, thyroid hormone, and milk production. Am. J. Vet. Res. 40:1792-1797.

John, S., M. Kale, N. Rathore, and D. Bhatnagar. 2001. Protective effect of vitamin $\mathrm{E}$ in Dimethoate and malathion induced oxidative stress in rat erythrocytes. J. Nutr. Biochem. 12:500-504.

Johnson, H. D. 1987. Bioclimate effects on growth, reproduction and milk production. Pages 35-57 in Bioclimatology and the Adaptation of Livestock, H. D. Johnson, ed. Elsevier, Amsterdam, The Netherlands.

Kehrer, J. P., and C. V. Smith. 1994. Free radicals in biology: sources, reactivities, and roles in the etiology of human dieseases. Pages 25-62 in Natural Antioxidants in Human Health and Diseases, B. Frei, ed. Academic Press, San Diego, CA.

Kusmic, C., E. Picano, C. L. Buscetti, C. Petersen, and R. Barsacchi. 2000. The antioxidant drug dipyridamole spares the vitamin $\mathrm{E}$ and thiols in red blood cells after oxidative stress. Cardiov. Res. 47:510-514

Maseki, M., I. Nishigaki, M. Hagihara, Y. Tomoda, and K. Yagi. 1981. Lipid peroxide levels and lipids content of serum lipoprotein fractions of pregnant subjects with or without pre-eclampsia. Clin. Chem. Acta 115:155-161.
Miller, J. K., E. Brzezinska-Slebodzinska, and F. C. Madsen. 1993. Oxidative stress, antioxidants, and animal function. J. Dairy Sci. 76:2812-2823.

Miller, J. K., and F. C. Madsen. 1994. Transition metals, oxidative status, and animal health: do alterations in plasma fast-acting antioxidants lead to disease in livestock? Pages 283-301 in Proc. Alltech's 10th Annu. Mtg. Nottingham University Press.

Nardone A., N. G. Lacetera, U. Bernabucci, and B. Ronchi. 1997. Composition of colostrum from dairy heifers exposed to high air temperatures during late pregnancy and early postpartum period. J. Dairy Sci. 80:838-844.

Noble, R. C., J. C. O'Kelly, and J. H. Moore. 1976. Observations on changes in lipid composition and lecitin-cholesterol-acyl transferase reaction of bovine plasma induced by heat exposure. Lipids $8: 216-223$.

Ohtsuka, Y., T. Kono, and Y. Kawakami. 1997. Oxidative stresses induced the cystine transport activity in human erythrocytes. Biochem. Biophys. Res. Commun. 155:160-166.

Passi, S., A. Stancato, and M. Cocchi., 2001. A monitoring of oxidative stress of ageing and ageing-related diseases. Prog. Nutr. 3:35-58.

Ronchi, B., U. Bernabucci, N. Lacetera, and A. Nardone. 2000. Oxidative and metabolic status of high yielding dairy cows in different nutritional conditions during the transition period. Page 125 in Proc. 51st Annu. Mtg. E.A.A.P., Vienna.

SAS 1996. User's Guide: Statistics, Version 6.11 Edition. SAS Inst., Inc., Cary, NC, USA.

Sies, H. 1991. Oxidative Stress: Oxidants and Antioxidants. Academic Press, San Diego, CA.

Spickett, C. M., J. Reglinski, W. E. Smith, R. Wilson, J. J. Walker, and J. McKillop. 1998. Erythrocytes glutathione balance and membrane stability during preeclampsia. Free Radic. Biol. Med. 24:1049-1055

Trevisan, M., R. Browne, M. Ram, P. Muti, J. Freudenheim, A. N. Carosella, and D. Armstrong. 2001. Correlates of markers of oxidative status in the general population. Am. J. Epidemiol 154:348-356.

Trout, J. P., L. R. McDowell, and P. J. Hansen. 1998. Characteristics of the estrous cycle and antioxidant status of lactating Holstein cows exposed to heat stress. J. Dairy Sci. 81:1244-1250.

Utoh, J., and H. Harasaki. 1992. Damage to erythrocytes from longterm heat stress. Clin. Sci. 82:9-11.

van den Berg, J. J. M., J. A. F. Op den Kamp, B. H. Lubin, B. Roelofsen, and F. A. Kuypers. 1992. Kinetic and site specificity of hydroperoxide-induced oxidative damage in red blood cells. Free Rad. Biol. Med. 12:487-498.

Webster A. J. F. 1991. Metabolic responses of farm animals to high temperature. EAAP Publ., 55:15-22.

Yu, B. P. 1994. Cellular defenses against damage from reactive oxygen species. Physiol. Rev. 74:139-162.

Zollner, H., R. J. Schaur, and H. Esterbauer. 1991. Biological activities of 4-hydroxyalkenals. Pages 337-397 in, Oxidative Stress: Oxidants and Antioxidants, H. Sies, ed. Academic Press, San Diego, CA. 